\title{
Validating a context-specific teacher critical pedagogy questionnaire
}

Roohani, Ali

Shahrekord University, Shahrekord, Iran (roohani.ali@gmail.com)

Hashemian, Mahmood

Shahrekord University, Shahrekord, Iran (m72h@hotmail.com)

Haghparast, Shahrzad $\bowtie$

Shahrekord University, Shahrekord, Iran (Sh.haghparast89@gmail.com)

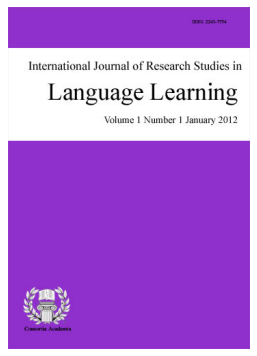

ISSN: 2243-7754 Online ISSN: 2243-7762

OPEN ACCESS

\section{Abstract}

Making a difference might be a teacher's desire in the classroom and critical pedagogy (CP) would appear to be a path to reach to that dream. Despite the rapid spread of English in Iran and the significance that critical pedagogy has attained in second/foreign language (L2) teaching, few studies have been conducted to survey Iranian English as a foreign language (EFL) teachers' critical pedagogy utilized in the classroom. Also, the lack of an instrument to measure the degree of critical pedagogy practiced in the classroom was highly remarkable. Due to the importance that critical pedagogy can have in the process of teaching and also on the students' way of thinking and given the lack of a valid test to assess L2 teachers' critical pedagogy, this study attempted to design and validate a context-specific questionnaire (Teacher Critical Pedagogy, TCP) to assess the degree of critical pedagogy practiced in the classroom by L2 teachers in the context of Iran. In order to test the reliability of the scale, Cronbach's alpha measure was used. Also, to examine the validity of TCP, evidence from content, concurrent and construct validity was obtained through triangulation methods. The results of factor analysis through the maximum likelihood estimation (MLE) technique with the data collected from a sample of 397 Iranian EFL (English as a foreign language) teachers, by using Analysis of Moment Structures (AMOS) software, confirmed the validity of the test with six sub-dimensions.

Keywords: critical pedagogy; questionnaire; validity; factor analysis; L2 teachers 


\section{Validating a context-specific teacher critical pedagogy questionnaire}

\section{Introduction}

Critical pedagogy (CP) has offered a new insight into language teaching that is probably beginning to influence the teaching of English to EFL learners. Based on Kanpol's (1998) view, in CP, students are coteachers and teachers are colearners, so to teach is to provide a context in which both teachers and learners can learn from each other, and teachers are not the only source of knowledge. In Degener's (2001) words, CP draws on critical theories which claim that education is political, and critical educators should educate students about the political and social inequities in addition to the materials being taught in the classroom. Larsen-Freeman and Anderson (2011) believe CP is an approach to teaching that aims to create a more egalitarian society by raising awareness of social injustice as a necessary part of the curriculum. In CP, educators, curriculum designers, and policymakers should learn about the culture, everyday experiences, language, and community that make up the reality of subordinated students (Freire, 1993; Giroux, 1997). CP is mainly concerned with developing in students and teachers the self-esteem to question the power relations in the society (McLaren, 2003). As Freire (1993) states, in CP, the teacher is seen as a problem poser, asking questions which encourage students to think analytically about aspects of their lives. As it was mentioned, in CP, learners are involved in the process of learning by bringing their own experiences to the classroom and relate education to their real-life problems. In $\mathrm{CP}$, learning takes place by the reflection of everyday life experiences in the classroom environment.

The significant role of CP in education and the role of society, values, government, and political changes in L2 classrooms are undeniable. Some of L2 students and teachers in Iran are not critical thinkers. Also, teachers are not aware of the marvelous capabilities of learners who can contribute a lot in the process of learning. Unfortunately, no specific questionnaire, to the best of the researchers' knowledge, has been developed specifically for L2 or EFL teachers in Iran to measure CP practiced in the classroom. Due to the aforementioned shortages and necessities, a need for the existence and development of a context-specific questionnaire was felt. Therefore, the current study attempted to develop a questionnaire to evaluate and assess the degree of $\mathrm{CP}$ practiced in the classroom by L2 teachers in the context of Iran.

\subsection{Critical Pedagogy}

According to Degener (2001), not all language programs are entirely critical due to the limitations that they may encounter. In the field of adult education, Degener (2001) claims that there is a CP framework for adult education programs using four degrees to categorize the level of criticalness of adult education courses: highly critical, somewhat critical, somewhat noncritical, and highly noncritical. This framework includes six elements of (1) philosophy, presuppositions, and goals, (2) program structure, (3) curriculum and materials, (4) teacher development, (5) teacher-student relationship, and (6) evaluation. In Degener's (2001) words, the philosophy behind CP is that education is political. Education in CP spins around political issues and inequities in society. To define program structure, based on what Giroux (1997) states, we can say that they are students and community members who are involved in program planning and their ideas and opinions are considered important in the planning process. In considering curriculum and materials in this program, the curriculum would always be linked as closely as possible to the immediate realities of the learners (Freire \& Macedo, 1987). CP materials are based on learners' needs, interests, and experiences.

To be able to inform learners of inequities in society, teachers themselves should be aware of social and political issues and injustice. To ensure that teachers are well aware of the factors that contribute to social inequalities, their preservice training program would include the study of critical theory, educational theory, linguistic theory, literacy theory, and social theory (Street, 1995). Teacher-student relationship is another element that means teachers and students collaborate with each other in the process of learning, and they learn a lot from 
Validating a context-specific teacher critical pedagogy questionnaire

each other. Finally, as Freire (1998) claims, an ongoing evaluation of both student and program progress is an essential part of a critical adult education program. Students set goals reflecting their needs and on a regular basis, teacher and students would discuss these goals and the progress made toward attaining them (Shor, 1992). Then, the students evaluate their progress based on whether they have met their goals or not (Degener, 2001). Thus, an adult education program may have a range of highly critical pedagogy toward a highly noncritical pedagogy based on the extent to which it reflects CP. This difference in degrees of criticalness deserves research to explore the significance that CP can have on education. In this light, studies on CP are reviewed here.

In one study, Rafi (2010) investigated effects of CP on the development of critical thinking through teaching English essay writing. The results showed that English essay writing promoted reasoning skills among the subjects by incorporating critical thinking in teaching. In their study, Barjesteh, Alipour, and Vaseghi (2013), attempted to investigate the effect of CP strategies on EFL learner's reading comprehension ability. The findings provide empirical support for the facilitative effect of $\mathrm{CP}$ strategy training on reading comprehension performance of EFL learners. Jorshari and Akbari (2013) examined the relationship between EFL learners' attitude toward $\mathrm{CP}$ and its impact on their academic writing achievement. The results proved a positive relationship between CP and learners' academic writing achievement. In another study, Shabani (2014) tried to investigate the relationship between EFL teachers' view on principle of CP and their educational success. The findings of the study revealed that the closer EFL teacher's methods were toward principles of $\mathrm{CP}$, the more successful in their job they were viewed by their students.

Although CP has received scholarly attention in the recent few decades, few attempts have been made to design reliable, valid and comprehensive instruments to study the degree of CP practiced in EFL classes. For example, in one study, Azimi (2008) developed and validated a CP questionnaire for Iranian English teachers, with a focus on the application of CP to the classroom. Yilmaz (2009) developed a 'Principles of Critical Pedagogy Scale' in Turkey to study school teachers' agreement with the principles of CP. Ghaffar Samar and Davari (2011) developed a questionnaire to study Iranian ELT professionals' and university teachers' attitudes on mainstream and critical ELT. This instrument has not been factor-analyzed. Davari, Iranmehr, and Erfani (2012) developed a questionnaire to study Iranian ELT community's attitudes to some practical implications of CP in ELT. This instrument, too, has not been factor-analyzed. In the light of the existing body of literature and the lack of a reliable and valid CP questionnaire in the context of Iran, this study attempts to develop and validate a questionnaire to gauge the degree of L2 teachers' CP utilized in EFL classrooms.

\section{Methodology}

\subsection{Participants}

To pilot Teacher Critical Pedagogy (TCP) questionnaire, 640 questionnaires were distributed among the English teachers who were in charge of teaching English courses in different English language institutes in the city of Isfahan, Iran, to validate the TCP questionnaire. After 50 days, 429 questionnaires were collected, however, 32 questionnaires were discarded from the analysis process due to the major data missing problems and only 397 questionnaires were considered for data entry and data analysis procedures. These teachers included females (177) and males (220), aged 20-55. After answering the TCP questionnaire, some of the teachers were interviewed to elicit their ideas about the items in the questionnaire to further ensure its validity.

\subsection{Instruments}

First, TCP, a Likert-type questionnaire, was constructed by the present researchers. The purpose of this questionnaire was to measure the degree of $\mathrm{CP}$ practiced in the classroom considering the literature on $\mathrm{CP}$, including Degener (2001), Freire (1970), and Yilmaz (2009), and experts' judgment. The final version of TCP questionnaire (See Appendix A) consisted of two main parts. The first part consisted of six categories of teacher personal characteristics related to (a) demographic information, such as gender, age, academic degree, years of 
teaching experience, and academic major, and (b) current teaching situations, such as numbers of teaching periods per week. The second part consisted of six themes and 35 items altogether. Each item was designed on a five-point Likert scale of agreement, where $1=$ strongly agree, $2=$ agree, $3=$ neutral, $4=$ disagree, and $5=$ strongly disagree (see Appendix A). The five-point Likert scale was employed as it would be one of the most commonly accepted Likert scales in the education field (Cheng, 2004; Cohen, 1976; Cohen \& Manion, 1989; Green, 2007; Gu, Wen, \& Wu, 1995). This part mainly dealt with the degree of CP practiced by the teachers who participated in this study in their classes.

\subsection{Procedure}

The TCP questionnaire used in the study was developed by the researcher (See Appendix A). In the development process of this questionnaire, in order to ensure validity and reliability, first of all, the researchers reviewed the relevant literature and examined the framework or questionnaires designed for similar purposes (e.g., Degener, 2001, Yilmaz, 2009). The first draft of the questionnaire was developed considering the issues pointed in the literature (Degener, 2001; Yilmaz, 2009; Freire, 1970; Bercaw \& Stooksberry, 2004). Then, two separate forms were designed for the questionnaire. The content validation form required the experts to rate each item of the questionnaire based on two criteria of the appropriateness of the item in representing the topic, and the clarity of the meaning of the item. The face validation form required the teachers to judge about the components of visual appeal, quality of instructions to respondents, scoring format, page layout, number of sections, number of items, wording of items, relevance of items to CP, and length of time needed to complete the questionnaire.

Then, the first draft of the questionnaire, content validation, and face validation forms were sent to three experts to be reviewed in order to ensure the content validity of the questionnaire. One of the experts was a lecturer at a state university in Iran who specialized in teaching methodology, and other experts were two TEFL lecturers at Islamic Azad University in Iran who were also interested in CP. This questionnaire was developed in English as the participants were teachers of English.

Based on the experts' suggestions, the first draft of the questionnaire was revised and the necessary changes were made in the second draft. Then, the second draft of the questionnaire was piloted on 640 English teachers who were in charge of teaching English courses in different English language institutes in Isfahan, Iran, to validate the TCP questionnaire. After 50 days, 429 questionnaires were collected, however, 32 questionnaires were discarded from the analysis process due to the major data missing problem and only 397 questionnaires were considered for data entry and analysis procedures. These teachers included females (177) and males (220), aged 20-55. After answering the TCP questionnaire, some of the teachers also, in an interview, were asked to express their opinions about the items and various aspects of the questionnaire to ensure construct validity.

\section{Data Analysis and Results}

Having calculated the scores of each individual participant on the questionnaires, the Statistical Package for Social Science (SPSS, version 21) and AMOS (version 5) were run to analyze the data. In order to examine the reliability of the scale, a reliability test was utilized, using Cronbach's alpha technique. As shown in Table 1, the Cronbach's alpha value for all the variables exceeded the minimum required value of 0.7 and hence, the scale of variables is highly reliable. The TCP questionnaire showed good internal consistency.

To examine the convergent and discriminant validity of the test, CFA (confirmatory factor analysis) was applied and the parameters were estimated using the MLE (the maximum likelihood estimation) technique. The regression weights were computed for each item. Based on the critical ratio (the estimate divided by the standard error), several items $(18,19,25-29,40$ and 41) were excluded from further analysis due to low factor loading values. The goodness of fit was assessed through the goodness of fit indicators (RMSEA, Chi-square, probability level of the related model, comparative fit index (CFI), non-normalized fit index (NNFI), and the standardized 
Validating a context-specific teacher critical pedagogy questionnaire

root mean square residual). RMSEA i.e., the corrected statistic that gives a penalty for model complexity was small. Besides, the non-significant Chi-square indices indicated no significant discrepancy between the model and the data (See Table 1). Thus, the questionnaire with 35 items had construct validity.

Table 1

The Results of the Reliability Estimates

\begin{tabular}{lcc}
\hline \multicolumn{1}{c}{ Variable } & No. of items & Cronbach's alpha \\
\hline Philosophical Orientation & 9 & 0.89 \\
Program Structure & 8 & 0.71 \\
Curriculum and Materials & 8 & 0.78 \\
Teacher Development & 6 & 0.81 \\
Teacher-Student Relationship & 7 & 0.83 \\
Evaluation & 6 & 0.84 \\
\hline
\end{tabular}

\section{Table 2}

Model Fitness for Measurement Model

\begin{tabular}{llllllllll}
\hline Fit Indices & $\chi^{2}$ & d.f & P & $\chi 2 /$ df & NNFI & CFI & RMSEA & RMSR & AGFI \\
\hline Result value & 1125.07 & 533 & 0.000 & 2.111 & 0.919 & 0.927 & 0.053 & 0.30 & 0.833 \\
\hline
\end{tabular}

The goodness of fit indices was calculated for the model and showed appropriate fit indices: $\left(\chi^{2}=1125.07\right.$, $\mathrm{CFI}=0.927$, NNFI=0.919, AGFI=0.833, RMSEA=0.30). Consequently, all of the obtained values for the final model shown in Table 2 indicated a good fit of the model. Therefore, the construct validity of the model was confirmed through $\mathrm{CF}$.

Table 3

The Loadings of the Critical Pedagogy Sub-dimensions Items

\begin{tabular}{clclll}
\hline Items & Corresponding Variables & Estimate & Items & Corresponding Variables & Estimate \\
\hline Q1 & Philosophical Orientation & 0.72 & Q21 & Teacher Development & 0.77 \\
Q2 & Philosophical Orientation & 0.69 & Q22 & Teacher Development & 0.77 \\
Q3 & Philosophical Orientation & 0.72 & Q23 & Teacher Development & 0.82 \\
Q4 & Philosophical Orientation & 0.63 & Q24 & Teacher Development & 0.75 \\
Q5 & Philosophical Orientation & 0.70 & Q25 & Teacher-Student Relationship & 0.73 \\
Q6 & Philosophical Orientation & 0.72 & Q26 & Teacher-Student Relationship & 0.78 \\
Q7 & Philosophical Orientation & 0.77 & Q27 & Teacher-Student Relationship & 0.74 \\
Q8 & Philosophical Orientation & 0.76 & Q28 & Teacher-Student Relationship & 0.82 \\
Q9 & Philosophical Orientation & 0.74 & Q29 & Teacher-Student Relationship & 0.81 \\
Q10 & Program Structure & 0.72 & Q30 & Teacher-Student Relationship & 0.73 \\
Q11 & Program Structure & 0.76 & Q31 & Evaluation & 0.63 \\
Q12 & Program Structure & 0.64 & Q32 & Evaluation & 0.67 \\
Q13 & Program Structure & 0.74 & Q33 & Evaluation & 0.63 \\
Q14 & Program Structure & 0.78 & Q34 & Evaluation & 0.79 \\
Q15 & Program Structure & 0.69 & Q35 & Evaluation & 0.74 \\
Q16 & Curriculum and Materials & 0.64 & & & \\
Q17 & Curriculum and Materials & 0.69 & & & \\
Q18 & Curriculum and Materials & 0.703 & & & \\
Q19 & Curriculum and Materials & 0.65 & & & \\
Q20 & Curriculum and Materials & 0.62 & & & \\
\hline
\end{tabular}

Furthermore, as illustrated in Table 4, composite reliability (CR) and average variance extracted (AVE) values for all the variables were found to be sufficiently high. Therefore, the convergent validity of the scale was ensured. Considering the discussed results, it can be concluded that the scale has sufficient validity. 
Roohani, A., Hashemian, M., \& Haghparast, S.

\section{Table 4}

The CR and AVE Values for Critical Pedagogy

\begin{tabular}{lcc}
\hline \multicolumn{1}{c}{ Variable } & AVE & CR \\
\hline Philosophical Orientation & 0.51 & 0.90 \\
Program Structure & 0.52 & 0.86 \\
Curriculum and Materials & 0.51 & 0.79 \\
Teacher Development & 0.59 & 0.93 \\
Evaluation & 0.82 & 0.82 \\
Teacher-Student Relationship & 0.60 & 0.90 \\
\hline
\end{tabular}

Three of fifty English teachers who participated in the pilot study were also randomly selected for cognitive interview (sometimes referred to as "thinking aloud" method). Such a method was employed as a procedure for construct validation to provide an opportunity for the respondents to react to various aspects of the questionnaire and make any additional remarks regarding the issues addressed in the survey (Cohen \& Manion, 1989). The aim of the cognitive interviews was to determine whether (a) the questionnaire items were understood as intended by the researcher, and (b) they were understood in the same way by all the teachers. Hence, the teachers' viewpoints on the questionnaire structure, the design of the categories, items and wordings helped to shape the final draft of the questionnaire and prepare it for the main study.

\section{Discussion}

Regarding language teaching and learning, $\mathrm{CP}$ is seen as one of the approaches with a critical view towards education and society. CP, due to its just nature and justice-seeking claims, is compatible with the social and religious values in Iran. In view of the appropriateness and essentiality of applying the principles of CP to the context of Iran, one does not need to justify the importance of the role that EFL teachers in general and English institute teachers play in the country. The development and validation of a questionnaire may be considered to be as a preliminary step for Iranian English teachers to enjoy criticalness, that is, paving the way to identify the extent to which Iranian private institute utilize the principles of CP. In so doing, a battery of 35 items was finally developed in the context of Iran. The act of piloting was done to ensure that questionnaire items are interpreted as much as possible in the same way by every survey respondent (Degener, 2001; Moafian \& Pishghadam, 2009). Cronbach's alpha coefficient was calculated for the questionnaire items to test the internal consistency of the items measuring the same construct. The Cronbach's alpha value for all the variables exceeded the minimum required value of 0.7. Although the obtained coefficients indicated a good internal reliability for the questionnaire, some items were deleted to increase the reliability and internal consistency of the questionnaire. Some minor changes in the wording of the items were also made considering the problems encountered during the pilot study. To examine the validity of TCP, evidence from content, concurrent and construct validity was obtained through triangulation methods. The results of factor analysis through the maximum likelihood estimation (MLE) technique confirmed the validity of the questionnaire with six sub-dimensions. The questionnaire developed in this study may be useful for researchers as a valid instrument to find the general and specific attitudes of teachers toward being critical in teaching career.

\section{Conclusion}

In Crookes and Lehner's (1998) words, CP in English should not be seen as a merely teaching method saying teachers how to teach English, but as a social and educational approach which is concerned about how English learning can lead to personal and social change. There has always been struggle between equality and inequality, balance and imbalance, as well as oppressed and oppressor in societies. The school as a small part of the society, in which we are living, can be a representative of this battle field. Teachers come to this little world (i.e., school) to depict these inequities and injustice, to make their students aware of these issues, ask them for their voice, for their awareness and their endeavor to identify these unfairness and power imbalance in society and pace towards removing them, making a world of justice which everyone dreams. Thus, due to the role that 
schools need to play to prepare students for living in the society, applying CP in the educational process could be a big asset to schools. As Giroux (1998) suggests, it is the job of education to make the students critical thinkers and encourage them to take a step in the direction of conducting a democratic life. Therefore, it should occur in an environment which connects education to students' everyday life and encourages them to discuss issues related to their lives that is conducted within the language and knowledge of them. Having political visions not only improves the life conditions of learners, but also a successful society itself is indebted to the political awareness of its citizens. To become able to identify inequities in society and to consider themselves a role of decision maker, students should be given the privilege of being exposed to materials which try to relate school to outside world and promote the sense of justice among them. Thus, including political and social issues in curriculum are of central issues that should be taken into account in CP.

Regarding the above-mentioned importance of CP in EFL teaching and learning and the absence of a valid questionnaire in this field in the context of Iran, the current study attempted to develop and validate a sound instrument to measure L2 teacher's degree of CP in EFL classes. The findings of this study represent two major implications: implications for research purposes and implications for educational organizations. The ability to identify, define and measure the facets of $\mathrm{CP}$ will provide the means to address a variety of research questions, for a range of correlational studies regarding the dynamics of L2 teaching and learning which have been largely untapped and investigate the relationships among teacher $\mathrm{CP}$ approaches and other teacher related constructs. The questionnaire can also be used to investigate the extent to which teachers' CP correlate with factors such as teachers' success, students' achievements, or other factors regarding EFL teaching and learning.

\section{References}

Azimi, H. (2008). On the attitude of English teachers and university students in the implementation of critical pedagogy. Unpublished master's thesis, Tarbiat Modares University, Tehran, Iran.

Bercaw, L. A., \& Stooksberry, L. M. (2004). Teacher education, critical pedagogy, and standards: An exploration of theory and practice. Essays in Education, 12. Retrieved from http://www.usca.edu/essays/vol122004/bercaw.pdf.html

Cheng, L. (2004). The washback effect of a public examination change on teachers' perceptions toward their classroom teaching. In L. Cheng, Y. Watanabe, \& A. Curtis (Eds.), Washback in language testing: Research contexts and methods (pp. 146-170). Mahwah, NJ: Lawrence Erlbaum Associates.

Cohen, L. \& Manion, L. (1989). Research methods in educations. London: Routledge.

Cohen, L. (1976). Educational research in classrooms and schools: A manual of materials and methods. London: Harper \& Row.

Crookes, G., \& Lehner, A. (1998). Aspects of process in an ESL critical pedagogy teacher education course. TESOL Quarterly, 32(2), 319-328. http://dx.doi.org/10.2307/3587586

Davari, H., Iranmehr, A., \& Erfani, S. M. (2012). A survey on the Iranian ELT community's attitudes to critical pedagogy. English Language Teaching, 5(2), 101-111. http://dx.doi.org/10.5539/elt.v5n2p101

Degener, S. (2001). Making sense of critical pedagogy in adult literacy education. The Annual Review of Adult Learning and Literacy, 2(2), 26-62.

Freire, P. (1970). Pedagogy of the oppressed. Continuum Publishing.

Freire, P. (1993). Pedagogy of the City. New York: Continuum.

Ghaffar Samar, R., \& Davari, H. (2011). Liberalist or alarmist: Iranian ELT community's attitude to mainstream ELT vs. critical ELT. TESOL Journal, 63(5), 63-91.

Giroux, H. A. (1997). Pedagogy and the politics of hope: Theory, culture, and schooling. Boulder, CO: Westview.

Giroux, H. A. (1998). Education in unsettling times: Public intellectuals and the promise of cultural studies. In D. Carlson \& M. Apple (Eds.), Power/knowledge/pedagogy, the meaning of democratic education in unsettling times (pp. 41-60). Boulder, CO: West View Press.

Green, A. (2007). Washback to learning outcomes: A comparative study of IELTS preparation and university 
Roohani, A., Hashemian, M., \& Haghparast, S.

pre-session language courses. Assessment in Education, 14(1), 75-97. http://dx.doi.org/10.1080/09695940701272880

Gu, Y., Wen, Q., \& Wu, D. (1995). How often is often? Reference ambiguities of the Likert-scale in language learning strategy research. Occasional Papers in English Language Teaching, 5, 19-35.

Izadinia, M. (2009). Critical pedagogy: An introduction. In P. Wachob (Ed.), Power in the EFL classroom: Critical pedagogy in the Middle East (pp. 7-16). Cambridge Scholars Publishing.

Kanpol, B. (1998). Critical pedagogy for beginning teachers: The movement from despair to hope. Online Journal of Critical Pedagogy, 2(1). Retrieved from http://users.monash.edu.criticalpedagogyforbeginningteacherBarryKanpol.html

Kessing-Styles, L. (2003). The relationship between critical pedagogy and assessment in teacher education. Radical Pedagogy, 5(1), 1-20.

Larsen-Freeman, D., \& Anderson, M. (2011). Techniques and principles in language teaching. New York: Oxford University Press.

Liu, C., Marchewka, J. T., Lu, J., Yu, C. (2004). Beyond concern: A privacy-trust-behavioral intention model of electronic commerce. Information \& Management, 42, 127-142. http://dx.doi.org/10.1016/j.im.2004.01.002

McLaren, P. (2003). Life in schools: An introduction to critical pedagogy in the foundations of education. San Francisco, CA: Allyn and Bacon Publishing Inc.

Moafian, F., \& Pishghadam, R. (2009). Construct validation of a questionnaire on characteristics of successful English language teachers. Pazhuhesh-e Zabanheye Khareji Journal, 54, 127-142.

Yilmaz, K. (2009). Elementary school teachers' views about the critical pedagogy. The Asia-Pacific Education Researcher, 18(1), 139-149. http://dx.doi.org/10.3860/taper.v18i1.1042 
Validating a context-specific teacher critical pedagogy questionnaire

Appendix A

\section{Teacher Critical Pedagogy (TCP) Questionnaire}

Dear Colleague,

This study aims to measure the degree of teacher critical pedagogy in general and in the classroom. To help us, please fill in this questionnaire according to your own opinions. All responses provided will be confidential and used for research purposes only. Thank you very much for your cooperation.

Please complete the chart below with the appropriate answer.

\begin{tabular}{|c|c|c|c|c|c|c|}
\hline Age: & $\begin{array}{l}\text { Teaching } \\
\text { Experience } \\
\text { (in years): }\end{array}$ & $\begin{array}{l}\text { Gender: } \\
\text { Male } \\
\text { Female }\end{array}$ & $\begin{array}{l}\text { Major: } \\
\text { Teaching } \\
\text { Linguistics }\end{array}$ & $\begin{array}{l}\text { Translation } \\
\text { Literature }\end{array}$ & $\begin{array}{l}\text { Degree: } \\
\text { BA/BSc } \\
\text { MA } \\
\mathrm{PhD}\end{array}$ & $\begin{array}{lc}\text { periods you teach } \\
\text { English per week: } \\
16-21 \quad 22-27 \\
28-33 \quad \text { above } 33\end{array}$ \\
\hline
\end{tabular}

Instructions: Read each item and show your level of agreement with it by choosing one of the five choices given. SA: Strongly Agree, A: Agree, N: Neutral, D: Disagree, and SD: Strongly Disagree

\begin{tabular}{|c|c|c|c|c|c|c|}
\hline No. & Statements & $\begin{array}{l}\mathrm{S} \\
\mathrm{A}\end{array}$ & A & $\mathrm{N}$ & $\mathrm{D}$ & $\begin{array}{l}\mathrm{S} \\
\mathrm{D}\end{array}$ \\
\hline 1 & $\begin{array}{l}\text { I think teachers should not enter/address the political and ideological issues } \\
\text { whatsoever in the classroom with the hope of changing society. }\end{array}$ & & & & & \\
\hline 2 & I think teachers should encourage students to have a critical look at the school. & & & & & \\
\hline 3 & I think teachers should be only authority in the classroom. & & & & & \\
\hline 4 & $\begin{array}{l}\text { I motivate my students to think critically about their own culture or previous } \\
\text { experiences in life. }\end{array}$ & & & & & \\
\hline 5 & $\begin{array}{l}\text { I believe I should involve all students in my class to promote equality and } \\
\text { justice. }\end{array}$ & & & & & \\
\hline 6 & I believe the main goal in my class is to convey information. & & & & & \\
\hline 7 & I am against injustice whether in the classroom or society. & & & & & \\
\hline 8 & I am the knower in the class. & & & & & \\
\hline 9 & I believe in dialogism (dialogue) to solve the problems in the classroom. & & & & & \\
\hline 10 & $\begin{array}{l}\text { In planning what to do in the classroom, I consider my students' expectations } \\
\text { and immediate needs. }\end{array}$ & & & & & \\
\hline 11 & $\begin{array}{l}\text { The students' future needs and interests are considered for organizing my class } \\
\text { agendas. }\end{array}$ & & & & & \\
\hline 12 & $\begin{array}{l}\text { For teaching language skills, I try to relate topics in the syllabus to my } \\
\text { students' social and cultural experiences. }\end{array}$ & & & & & \\
\hline 13 & In my class, I just follow the goals and objectives of the program. & & & & & \\
\hline 14 & My program tends to make students effective decision makers. & & & & & \\
\hline 15 & In program planning, my students are involved. & & & & & \\
\hline 16 & Needs analysis is an essential part of my program. & & & & & \\
\hline 17 & My students are not knowledgeable enough for program planning. & & & & & \\
\hline 18 & I adapt the teaching materials to suit my students in the class. & & & & & \\
\hline 19 & $\begin{array}{l}\text { As an activity, I request students to express their viewpoints about teaching } \\
\text { materials and topics. }\end{array}$ & & & & & \\
\hline 20 & In my teaching, I try to follow the pre-set curriculum and text books. & & & & & \\
\hline 21 & My curriculum is strictly formal, paying little attention to underlying values. & & & & & \\
\hline 22 & My instruction and teaching materials seek to make students become critiques. & & & & & \\
\hline 23 & $\begin{array}{l}\text { In my class, I do not find enough time to learn about my students' hopes, } \\
\text { needs and interests. }\end{array}$ & & & & & \\
\hline
\end{tabular}


Roohani, A., Hashemian, M., \& Haghparast, S.

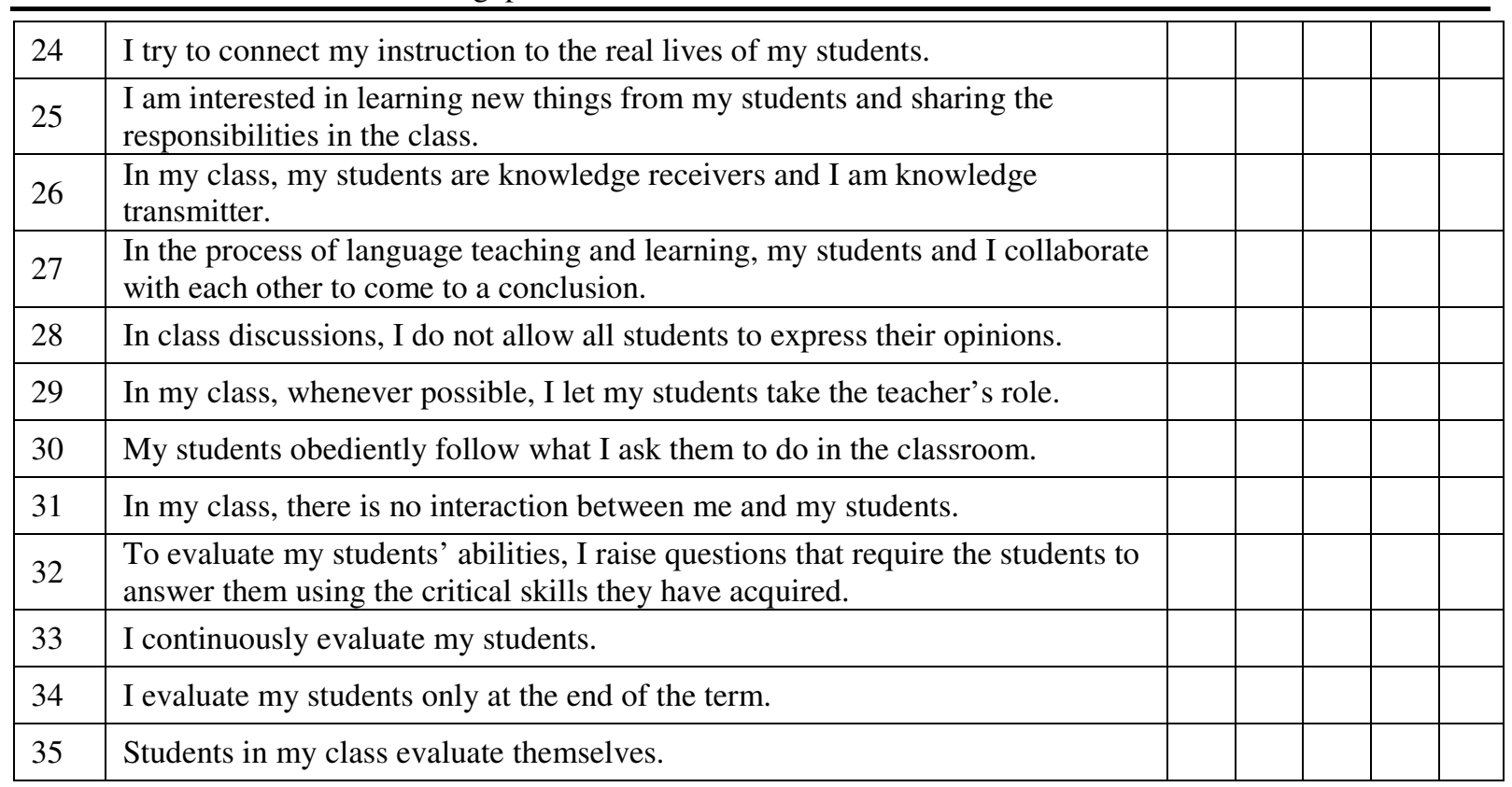

